\title{
PENGARUH ARANG KOMPOS BIOAKTIF TERHADAP PERTUMBUHAN ANAKAN BULIAN (Eusyderoxylon zwageri) DAN GAHARU (Aquilaria malaccensis)
}

\section{(The Influence of Bioactive Charcoal Compost on Seedlings Growth of Bulian (Eusyderoxylon zwageri) and Agarwood (Aquilaria malaccensis)}

\author{
Oleh/By : \\ Gusmailina \\ ${ }^{1}$ Pusat Penelitian dan Pengembangan Hasil Hutan, Jl. Gunung Batu No. 5 Bogor \\ Telp. (0251) 8633378, Fax. (0251) 8633413
}

Diterima 8 Maret 2010 disetujui 3 Agustus 2010

\begin{abstract}
This article presents several effective growth indications of bulian (Eusyderoxylon zwageri) and agarwood (Aquilaria malaccensis) seedlings wbich planted in various media of bioactive charcoal compost.

This study employed two main compositions of sawdust activated compost, i.e., sawdust bioactivated compost (ASG) and the ASG plus ricestraw (ASGJ). The research was conducted through 4 months observation in a seedbed belong to Government Forestry District in Jambi.

Experiments were completely randomize designed with various portions of ASG and ASGJ ranging from $15 \%$ to $50 \%$. Growth media contained similar portions of conventional compost were used for comparison, while the control simply contained $100 \%$ of top soil. Parameters observed in this study consisted of growth percentage, height, and stem diameter increaments. The collected data were then analized according to Duncan and Scheffe test.

Results indicated that the seedling growth of bulian and gabaru in ASG and ASGJ media were better than those planted in conventional compost or control media.
\end{abstract}

Keywords: Activated charcoal compost, media, seedling, bulian, agar wood

\section{ABSTRAK}

Tulisan ini menyajikan beberapa indikasi pengaruh penggunaan arkoba sebagai campuran media terhadap pertumbuhan anakan bulian (Eusyderoxylon zwageri) dan anakan gaharu (Aquilaria malaccensis), dua jenis tanaman andalan setempat yang sedang dikembangkan. Penelitian ini menggunakan dua komposisi utama, yaitu penambahan arkoba serbuk gergaji (ASG) dan arkoba serbuk gergaji yang dicampur dengan jerami padi (ASGJ). Penelitian dilakukan selama 4 bulan di kebun bibit Dinas Kehutanan Propinsi Jambi, di Jambi.

Percobaan menggunakan rancangan acak lengkap dengan perlakuan ASG dan ASGJ masingmasing $15 \%, 30 \%$, dan $50 \%$. Sebagai pembanding digunakan kompos dalam porsi yang sama serta kontrol (top soil 100\%). Parameter yang diamati adalah persentase tumbuh, pertambahan tinggi dan diameter batang. Data hasil penelitian dianalisa menurut uji beda jarak Duncan, selanjutnya perbedaan respon tumbuhan secara lebih spesifik antara kontrol dengan setiap perlakuan diuji dengan cara Scheffe. 
Hasil penelitian menunjukkan bahwa pertumbuhan anakan bulian dan gaharu pada media ASG dan ASGJ secara nyata lebih baik dari pada pertumbuhannya pada media kompos konvensional maupun kontrol. Pertambahan tinggi dan diameter anakan pada ke dua media serbuk kompos tersebut dapat mencapai $400 \%$ dibandingkan dengan pertumbuhan pada media kontrol.

Kata kunci: Arkoba, media, anakan, bulian, gaharu

\section{PENDAHULUAN}

Arang kompos bioaktif (Arkoba) adalah campuran arang dan kompos hasil proses pengomposan dengan bantuan mikroba lignoselulotik yang tetap hidup di dalam kompos. Mikroba tersebut mempunyai kemampuan sebagai biofungisida, yaitu melindungi tanaman dari serangan penyakit akar sehingga disebut bioaktif. Keunggulan lain dari Arkoba adalah sebagai agent pembangun kesuburan tanah, karena arang yang menyatu dalam kompos mampu meningkatkan $\mathrm{pH}$ tanah sekaligus memperbaiki sirkulasi air dan udara di dalam tanah (Gusmailina dan Komarayati, 2008)

Arkoba dibuat dalam rangka optimalisasi dan pemanfaatan limbah industri perkayuan terutama serbuk gergaji. Akan tetapi arkoba juga dapat dimanfaatkan untuk pengolahan limbah organik lainnya, baik yang berasal dari sampah rumah tangga, pertanian, perkebunan atau sampah kota (Gusmailina, Pari dan Komarayati, 2002).

Tulisan ini menyajikan hasil penelitian pemanfaatan limbah serbuk gergaji dari industri perkayuan. Arkoba yang dihasilkan selanjutnya diuji coba sebagai campuran media pertumbuhan anakan bulian (Eusyderoxylon zwager) dan gaharu (Aquilaria malaccensis). Ke dua tanaman ini merupakan jenis andalan setempat yang sedang dikembangkan. Tujuan penelitian adalah untuk mengetahui pengaruh penambahan arkoba serbuk gergaji (ASG) dan arkoba serbuk gergaji dicampur dengan jerami padi (ASGJ).

\section{BAHAN DAN METODE}

\section{A. Bahan dan Alat}

Bahan yang digunakan yaitu kompos (K), arkoba serbuk gergaji (ASG) dan arkoba serbuk gergaji yang dicampur dengan jerami padi (ASGJ) sebagai media pertumbuhan. Bibit bulian (E. zwageri) dan bibit gaharu (A. malaccensis) serta tanah lapisan permukaan (top soil). Peralatan yang digunakan antara lain : polybag (kantong plastik media tumbuh), alat pengukur tinggi dan diameter batang, dan selang plastik untuk menyiram.

\section{B. Lokasi Penelitian}

Penelitian dilakukan selama 4 bulan di kebun bibit Dinas Kehutanan Propinsi Jambi, di Jambi. 


\section{Prosedur Kerja}

\section{Rancangan percobaan}

Penelaahan data percobaan menggunakan rancangan percobaan berpola acak lengkap, sebagai perlakuan adalah :

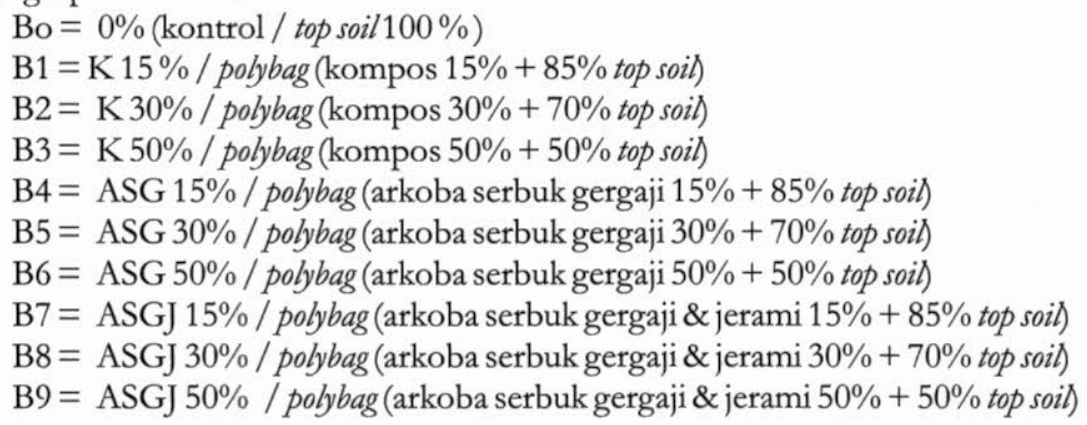

Masing-masing perlakuan diulang sebanyak $10 \mathrm{kali}$, sehingga jumlah sampel seluruhnya sebanyak 90 buah. Jika pengaruh perlakuan nyata, selanjutnya diuji beda jarak Duncan (Steel dan Torrie, 1991). Untuk mengetahui perbedaan respon tumbuhan secara lebih spesifik antara B0 (kontrol) dengan perlakuan gabungan kompos (K), ASG dan ASGJ; antara K $15 \%, 30 \%$ dan 50\%; antara ASG 15\%, 30\% dan 50\%; dan antara ASGJ 15\%, 30\% dan $50 \%$, digunakan metode uji cara Scheffe (Steel dan Torrie, 1991).

\section{Pembuatan media}

Tanah (top soil) dicampur dengan kompos/arkoba sampai merata dengan volume $4 \mathrm{~kg}$ per polybag. Dosis kompos dan arkoba disesuaikan dengan perlakuan. Setelah tercampur rata, dimasukkan ke dalam polybag, disiram dengan air sampai terserap oleh media kemudian ditanami dengan anakan bulian dan gaharu. Polybag yang telah berisi media dan ditanami, diletakkan di atas bedengan pesemaian, disiram dengan air secukupnya setiap hari selama 4 bulan penelitian.

\section{Analisis unsur hara}

Media yang digunakan dianalisis unsur haranya terlebih dahulu. Analisis dilakukan di laboratorium tanah, Biotrop Bogor. Analisis unsur N dilakukan dengan metode Kejdahl (Sukmana, 1983 dalam Anonim, 2000). Penetapan kadar C organik dengan metode Walkey dan Black, Ca total ditetapkan menurut prosedur Saeni dan Latifah (1990). Sedangkan P total, $\mathrm{K}$ total, $\mathrm{Mg}$ total, $\mathrm{KTK}$, kadar air, $\mathrm{pH}$ ditetapkan mengikuti prosedur pengujian Biotrop (Anonim, 2000).

\section{Pengumpulan data}

Media Data yang diamati yaitu persentase tumbuh, pertambahan tinggi, dan diameter batang. Persentase tumbuh anakan dihitung dari jumlah anakan yang hidup sampai akhir pengamatan dikurangi jumlah anakan saat awal tanam. Pertambahan tinggi anakan dihitung berdasarkan selisih antara tinggi anakan akhir pengamatan dengan tinggi anakan awal tanam (Tinggi akhir-Tinggi awal), demikian juga dengan persentase pertambahan diameter batang anakan yaitu selisih antara diameter akhir pengamatan dengan diameter awal tanam (diameter akhir-diameter awal). 


\section{Analisis Data}

Hasil pengamatan diolah dengan menggunakan pola acak lengkap (Steel dan Torrie, 1991). Selanjutnya untuk mengetahui adanya perbedaan pengaruh antar perlakuan, dilakukan uji beda nyata dengan cara Duncan yang dilanjutkan dengan uji perbandingan menggunakan cara Scheffe (Steel dan Torrie, 1991).

\section{HASIL DAN PEMBAHASAN}

\section{A. Analisis Kandungan Unsur Hara K, ASG dan ASGJ}

Hasil analisis kandungan unsur hara dapat dilihat pada Tabel 1.

Tabel1. Kandungan unsur hara kompos (K), Arkoba serbuk gergaji, dan arkoba serbuk gergaji + jerami padi sebagai campuran media tumbuh anakan bulian (E. Zwageri) dan gaharu (A.Malaccensis)

Table 1. Nutrient content of compost, sawdust bioactive charcoal compost, sawdust + rice straw bioactive charcoal compost as growth media of bulian (E.zwageri) and gabaru (A. malaccensis) seedling

\begin{tabular}{|c|c|c|c|c|c|}
\hline \multirow{2}{*}{ No. } & \multirow{2}{*}{ Parameter (Parameters) } & \multicolumn{3}{|c|}{ Nilai (Value) } & \multirow{2}{*}{$\begin{array}{c}\text { Standar } \\
(\text { Standard }) \\
*)\end{array}$} \\
\hline & & $\begin{array}{l}\text { Kompos } \\
\text { (Compost) }\end{array}$ & ASG & ASGJ & \\
\hline 1 & $\mathrm{pH}(1: 1,25)$ & 7,10 & 7,30 & 7,20 & 7,30 \\
\hline 2 & $\begin{array}{l}\text { Kadar air (Moisture content) } \\
105^{\circ} \mathrm{C}, \%\end{array}$ & 19,63 & 23,03 & 24,13 & 24,90 \\
\hline 3 & C organik ( $C$ organic), $\%$ & 11,46 & 32,45 & 34,98 & 19,60 \\
\hline 4 & Nitrogen total $($ Total N), \% & 0,6 & 1,53 & 1,78 & 1,10 \\
\hline 5 & Nisbah $\mathrm{C} / \mathrm{N}(C / N$ ratio $)$ & 19,1 & 21,20 & 19,65 & $10-20$ \\
\hline 6 & $\mathrm{P}_{2} \mathrm{O}_{5}$ total, $\%$ & 0,23 & 2,12 & 2,16 & 1,80 \\
\hline 7 & $\mathrm{CaO}$ total, $\%$ & 0,43 & 0,97 & 0,83 & 2,70 \\
\hline 8 & $\mathrm{MgO}$ total, $\%$ & 0,37 & 1,67 & 1,61 & 1,60 \\
\hline 9 & $\mathrm{~K}_{2} \mathrm{O}$ total, $\%$ & 0,51 & 2,19 & 2,34 & 1,40 \\
\hline 10 & $\begin{array}{l}\text { KTK (Cation exchange capacity), } \\
\mathrm{meq} / 100 \mathrm{gr}\end{array}$ & 21,32 & 36,42 & 36,61 & 30,00 \\
\hline
\end{tabular}

Keterangan (Remarks): ASG Arkoba serbuk gergaji (sawdust bioactive charcoal compost); ASGJ Arkoba serbuk gergaji + jerami padi (sawdust + rice straw bioactive charcoal compost); *) Anonim (2000)

Pada Tabel 1 diketahui bahwa secara umum kualitas arkoba ASGJ sedikit lebih baik dari arkoba ASG dan kompos. Hal ini dapat dilihat dari total kandungan C-organik, Nitrogen, Posfat $\left(\mathrm{P}_{2} \mathrm{O}_{5}\right)$, Kalium $\left(\mathrm{K}_{2} \mathrm{O}\right)$ dan KTK. Kandungan C-organik ASGJ, ASG, kompos dan standar secara berurut masing-masing 34,98\%, 32,45\%, 11,46\% dan 19,60\%. Jumlah C-organik dalam tanah menunjukkan banyaknya bahan organik yang terkandung, dan 
itu dapat menentukan tingkat interaksi antara komponen abiotik dan biotik dalam ekosistem tanah. Menururt Hanafiah et al., (2005), kandungan bahan organik dalam bentuk C-organik di tanah harus dipertahankan tidak kurang dari 2 persen. Agar kandungan bahan organik dalam tanah tidak menurun akibat proses dekomposisi (mineralisasi), penambahan harus diberikan setiap tahun, yaitu pada waktu pengolahan tanah. Selain itu kandungan bahan organik juga berkaitan erat dengan Kapasitas Tukar Kation (KTK), sehingga tanpa penambahan bahan organik tanah akan mengalami degradasi kimia, fisik, dan biologi menyebabkan agregat tanah merusak dan menjadi padat (Anonim 1991).

Kandungan N total ASGJ (1,78\%) lebih tinggi dari ASG (1,53) masing-masing di atas standar minimal (1,10\%). Hal itu mungkin disebabkan karena bahan baku yang dipakai pada percobaan proses pengomposan ASGJ adalah serbuk gergaji dicampur dengan jerami padi. Diketahui bahwa jerami padi merupakan bahan campuran yang mengandung nitrogen yang tinggi (Kim and Dale, 2004), sehingga selain proses pengomposannya lebih cepat, juga kualitas hasil yang diperoleh terutama kandungan hara $\mathrm{N}$ totalnya lebih tinggi.

Kandungan $N$ total umumnya berkisar antara $2000-4000 \mathrm{~kg} / \mathrm{h}$ a pada lapisan $0-20 \mathrm{~cm}$. tetapi yang tersedia bagi tanaman kurang 3\% dari total tersebut (Hardjowigeno, 2003). Dikemukakan juga bahwa manfaat dari nitrogen adalah untuk memacu pertumbuhan tanaman pada fase vegetatif, serta berperan dalam pembentukan klorofil, asam amino, lemak dan enzim. Nitrogen terdapat di dalam tanah dalam bentuk organik dan anorganik. Bentukbentuk anorganik meliputi $\mathrm{NH}_{4}, \mathrm{NO}_{3}, \mathrm{NO}_{2}, \mathrm{~N}_{2} \mathrm{O}$ dan unsur $\mathrm{N}$. Tanaman menyerap unsur ini terutama dalam bentuk $\mathrm{NO}_{3}$, namun bentuk lain yang juga dapat diserap adalah $\mathrm{NH}_{4}$, dan urea dalam bentuk $\mathrm{NO}_{3}$. Rinsema (1993), juga mengemukakan bahwa tumbuhan memperoleh nitrogen dari dalam tanah berupa amonia $\left(\mathrm{NH}_{3}\right)$, ion nitrit $\left(\mathrm{NO}_{2^{-}}\right)$, dan ion nitrat $\left(\mathrm{NO}_{3}^{-}\right)$, atau garam amonium $\left(\mathrm{NH}_{4}^{+}\right)$.

Dalam siklusnya, nitrogen organik di dalam tanah mengalami mineralisasi (bahan organik $\rightarrow \mathrm{CO}_{2} \rightarrow \mathrm{H}_{2} \mathrm{O}+$ mineral) dan bahan mineral yang terbentuk perlu peran mikroba untuk mengurainya. Sebagian $\mathrm{N}$ terangkut, sebagian kembali sebagai residu tanaman, hilang ke atmosfer dan kembali lagi. N yang hilang dapat melalui pencucian tapi akan bertambah lagi melalui pemupukan (Gambar 1). Nitrogen yang diikat biasanya dalam bentuk amonia. Amonia diperoleh dari hasil penguraian jaringan yang mati oleh bakteri. Amonia ini akan dinitrifikasi oleh bakteri nitrit, yaitu Nitrosomonas dan Nitrosococcus sehingga menghasilkan nitrat yang akan diserap oleh akar tumbuhan. Selanjutnya oleh bakteri denitrifikan, nitrat diubah menjadi amonia kembali, dan amonia diubah menjadi nitrogen yang dilepaskan ke udara. Dengan cara ini siklus nitrogen akan berulang dalam ekosistem.

Kandungan P (fosfor) arkoba ASGJ dan ASG masing-masing 2,16\% dan 2,12\%, lebih tinggi dari kompos $0,23 \%$, bahkan dari standar $1,80 \%$. Umumnya unsur $\mathrm{P}$ dalam tanah berasal dari bahan organik, pupuk buatan dan mineral di dalam tanah. Fosfor paling mudah diserap oleh tanaman pada $\mathrm{pH}$ sekitar 6-7 (Hardjowigeno, 2003). Dalam siklus fosfor (Gambar 2), kadar P-larutan merupakan hasil keseimbangan antara suplai dari pelapukan mineral P, pelarutan P-terfiksasi dan mineralisasi P-organik. Menurut Leiwakabessy (1988) di dalam tanah terdapat dua jenis fosfor yaitu fosfor organik dan fosfor anorganik. Bentuk P organik biasanya terdapat di lapisan atas yang lebih kaya akan bahan organik. Kadar P organik dalam bahan organik kurang lebih sama kadarnya dengan yang terdapat pada dalam tanaman yaitu 0,2 - 0,5\%. Tanah-tanah tua di Indonesia (Podsolik dan Litosol) umumnya berkadar P rendah, sehingga penanaman tanpa memperhatikan suplai P kemungkinan besar akan gagal 
akibat defisiensi P (Hanafiah et al., 2005). Selain itu jika kekurangan unsur P, pembelahan sel pada tanaman terhambat dan pertumbuhannya kerdil.

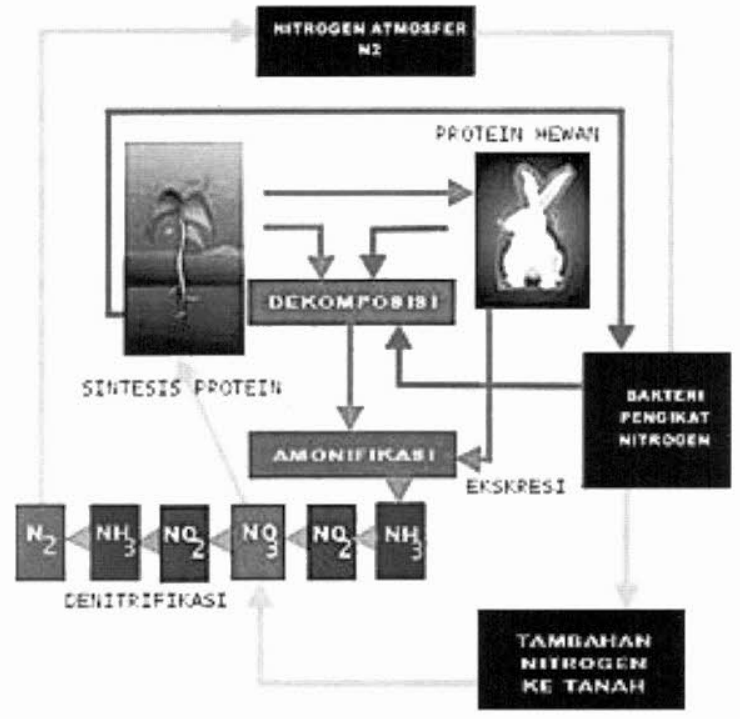

Gambar 1. Siklus Nitrogen di alam (Sumber Rinsema, 1993; Hardjowigeno 2003) Figure 1. Nitrogen cycle in nature (Source Rinsema, 1993; Hardjowigeno 2003)

Siklus Fosfor

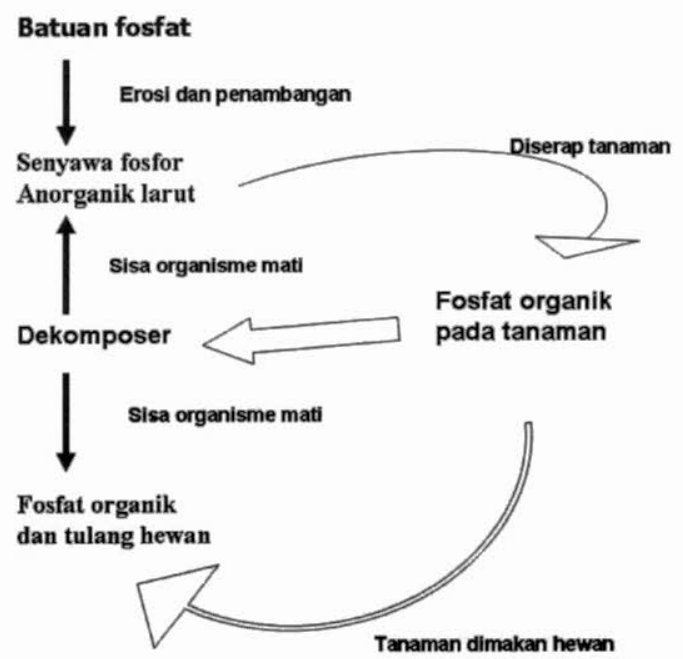

Gambar 2. Siklus P di alam (Anonim, 2009) Figure 2. P cycle in nature (Anonymous, 2009) 
Kandungan kalium ASG (2,19\%) dan ASGJ (2,34\%), lebih tinggi dari yang terkandung pada kompos $(0,51 \%)$ dan standar $(1,40 \%)$. Kalium merupakan unsur hara ketiga setelah nitrogen dan fosfor yang diserap oleh tanaman dalam bentuk ion $\mathrm{K}+$. Hakim et al., (1986), menyatakan bahwa ketersediaan kalium yang dapat dipertukarkan dan dapat diserap tanaman, tergantung penambahan dari luar. Umumnya kalium tanah terbentuk dari pelapukan batuan dan mineral yang mengandung kalium. Melalui proses dekomposisi bahan tanaman dan jasad renik, kalium akan larut dan kembali ke tanah. Sebagian besar kalium tanah yang larut akan tercuci atau mengalami erosi, dan akan lebih cepat lagi kalau diserap tanaman.

\section{B. Persentase Tumbuh Anakan}

Setelah empat bulan ditanam jumlah anakan yang hidup dihitung. Pengaruh pemberian arang kompos bioaktif terhadap persentase tumbuh anakan bulian dan gaharu dapat dilihat pada Tabel 2 .

Tabel 2. Pengaruh pemberian arang kompos bioaktif terhadap persentase tumbuh anakan bulian dan gaharu (\%)

Table 2.The effect of bioactive charcoal compost on growth percentage of bulian (E.zwageri) and gabaru (A. malaccensis), Seedlings, \%

\begin{tabular}{|l|c|c|c|c|}
\hline \multirow{2}{*}{$\begin{array}{c}\text { Jenis } \\
\text { (Species) }\end{array}$} & \multicolumn{3}{|c|}{ Persentase tumbuh (Growth percentage) / perlakuan (Treatment), \% } \\
\cline { 2 - 5 } & $\begin{array}{l}\text { Kompos } \\
\text { (Compost) }\end{array}$ & $\begin{array}{l}\text { Kompos } \\
\text { (Compost) }\end{array}$ & $\begin{array}{l}\text { ASG (Sawdust } \\
\text { bioactive charcoal } \\
\text { compost) }\end{array}$ & $\begin{array}{l}\text { ASGJ } \\
\text { (Sawdust +rice straw } \\
\text { bioactive charcoal } \\
\text { compost) }\end{array}$ \\
\hline $\begin{array}{l}\text { Bulian } \\
\text { (E. zwageri) }\end{array}$ & 87 & 93 & 100 & 100 \\
\hline $\begin{array}{l}\text { Gaharu } \\
(\text { A. malaccensis) }\end{array}$ & 81 & 89 & 100 & 100 \\
\hline
\end{tabular}

Persentase tumbuh anakan tanpa perlakuan (B0) adalah 87\% untuk anakan bulian, dan $81 \%$ untuk anakan gaharu. Sedangkan persentase tumbuh anakan pada perlakuan kompos (K) adalah 93\% pada anakan bulian, dan 92\% untuk anakan gaharu. Persentase tumbuh anakan pada perlakuan ASG dan ASGJ menunjukkan persentase tumbuh yang sama yaitu $100 \%$ hidup.

Persentase tumbuh anakan yang ditanam pada media yang dicampur dengan arkoba, baik arkoba ASG maupun arkoba ASGJ memberikan pertumbuhan anakan yang lebih baik yaitu $100 \%$. Artinya selama pengamatan tidak ada anakan yang mati. Sedangkan anakan yang ditanam pada media kompos rata-rata persentase tumbuh anakan hanya mencapai $91 \%$. Sementara rata-rata persentase anakan yang tumbuh pada media tanah saja (tanpa perlakuan) hanya $84 \%$. Dengan demikian selama 4 bulan pengamatan arkoba memberikan respon yang sangat baik terhadap pertumbuhan anakan bulian maupun gaharu. Hal ini disebabkan karena kualitas arkoba lebih baik dari kompos biasa yang dihasilkan secara konvensional. Juga disebabkan karena keberadaan arang yang menyatu dengan kompos, sehingga dengan cepat 
dapat memperbaiki kondisi lingkungan perakaran sekaligus dapat memperbaiki sifat fisik, kimia, dan biologi tanah yang membuat pertumbuhan tanaman menjadi lebih baik (Gusmailina, 2007 dan 2009). Selain itu dengan keberadaan arang yang menyatu dalam arkoba, menjadikan media lebih porous sehingga sirkulasi air dan udara di dalam media lebih baik. Kondisi inilah yang memungkinkan sehingga persentase anakan yang tumbuh pada media arkoba $100 \%$.

\section{Pertambahan Tinggi Anakan}

Hasil penelitian pertambahan tinggi tanaman dapat diketahui pada Tabel 3.

Tabel 3. Rataan pertambahan tinggi anakan bulian dan gaharu selama 4 bulan Table 3. Means of bulian (E.zwageri) and gabaru (A. malaccensis) beight growth seedlings during 4 month

\begin{tabular}{|c|c|c|}
\hline \multirow{2}{*}{$\begin{array}{l}\text { Perlakuan } \\
\text { (Treatment) }\end{array}$} & \multicolumn{2}{|c|}{$\begin{array}{l}\text { Pertambahan tinggi } \\
\text { (Heigth growth), } \mathrm{cm}\end{array}$} \\
\hline & $\begin{array}{c}\text { Bulian } \\
\text { (E.zwageri) }\end{array}$ & $\begin{array}{l}\text { Gaharu (A. } \\
\text { malaccensis) }\end{array}$ \\
\hline B0 (Kontrol/Control) & $11,13 \mathrm{~h}$ & $10,26 \mathrm{~g}$ \\
\hline B1 Kompos (Compost) 15\% & $19,27 \mathrm{~g}$ & $21,27 \mathrm{f}$ \\
\hline B2 Kompos (Compost) 30\% & $19,85 \mathrm{~g}$ & $20,61 \mathrm{f}$ \\
\hline B3 Kompos (Compost) 50\% & $22,12 \mathrm{~g}$ & $22,62 \mathrm{f}$ \\
\hline B4 ASG (Sawdust bioactive charcoal compost) $15 \%$ & $30,22 \mathrm{e}$ & $23,87 \mathrm{f}$ \\
\hline B5 ASG (Sawdust bioactive charcoal compost) $30 \%$ & $37,81 \mathrm{~d}$ & $25,71 \mathrm{e}$ \\
\hline B6 ASG (Sawdust bioactive charcoal compost) $50 \%$ & $37,96 \mathrm{~d}$ & $26,79 \mathrm{~d}$ \\
\hline B7 ASGJ (Sawdust + rice straw bioactive charcoal compost) $15 \%$ & $40,19 \mathrm{c}$ & $37,19 \mathrm{c}$ \\
\hline B8 ASGJ (Sawdust + rice straw bioactive charcoal compost) $30 \%$ & $44,61 \mathrm{~b}$ & $39,45 \mathrm{~b}$ \\
\hline B9 ASGJ (Sawdust + rice straw bioactive charcoal compost $50 \%$ & $46,73 \mathrm{a}$ & $40,52 \mathrm{a}$ \\
\hline
\end{tabular}

Keterangan (Remarks) : Angka yang diikuti huruf sama pada kolom yang sama tidak berbeda nyata pada uji Duncan taraf 5\% (Numbers followed by the same letters in the same column are not significantly different by Duncan Test)

Pada Tabel 3, dapat diketahui bahwa perlakuan B0 atau kontrol menunjukkan pertambahan tinggi anakan paling rendah yaitu sebesar $11,13 \mathrm{~cm}$ untuk anakan bulian (E. 2wager) dan 10,26 cm untuk anakan gaharu (A.malaccensis). Pertambahan yang paling tinggi dijumpai pada perlakuan B9 sebesar $46,73 \mathrm{~cm}$ pada anakan bulian dan $40,52 \mathrm{~cm}$ pada anakan gaharu.

Penambahan arkoba pada media dapat merangsang pertumbuhan tanaman, karena arkoba mengandung unsur hara makro yang lengkap dan berguna bagi tanaman (Komarayati, et al., 2003). Pada Gambar 3 dapat dilihat dengan jelas bahwa pertambahan tinggi ke dua jenis anakan yang tumbuh pada media arkoba (B4-B9) jauh lebih baik 
dibanding kontrol (B0) dan kompos biasa (B1-B3). Dengan demikian penambahan penambahan arkoba pada perlakuan B9 merupakan komposisi terbaik bagi pertambahan tinggi anakan bulian dan gaharu. Namun untuk penerapan aplikasi selanjutnya, perlakuan B8 lebih efisien dibanding B9, karena penambahan arang kompos bioaktifnya lebih sedikit sementara pertambahan tinggi relatif sama.

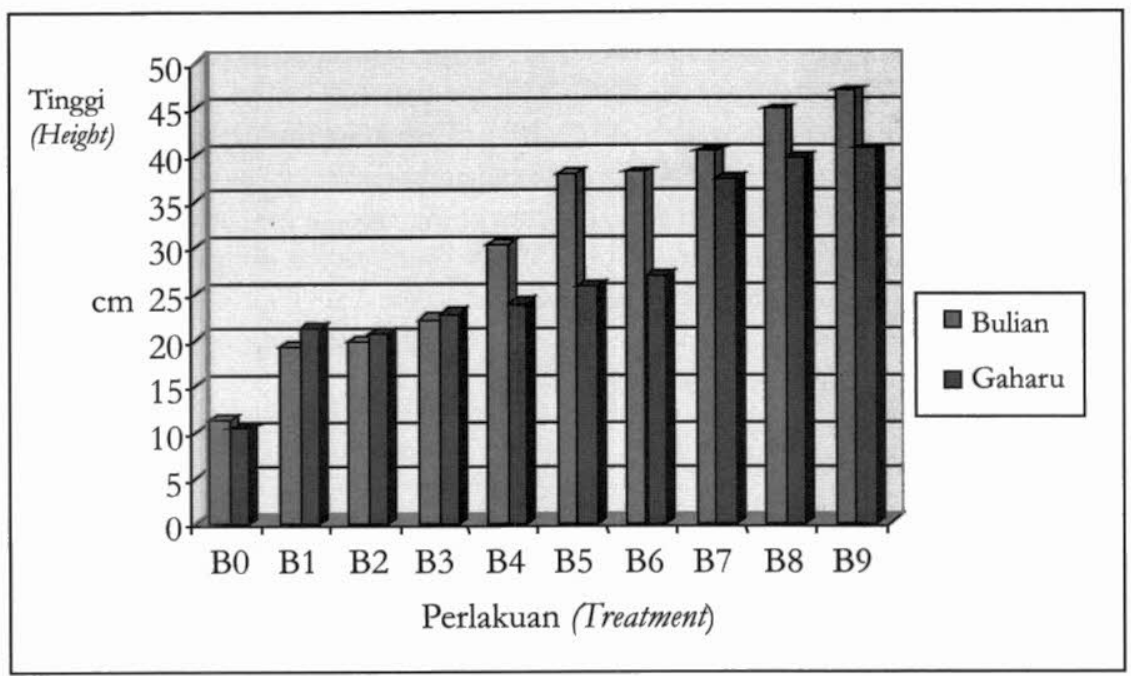

Gambar 3. Pengaruh pemberian arkoba terhadap pertambahan tinggi anakan bulian (E.zwageri) dan gaharu (A.malaccensis) selama 4 bulan.

Figure 3. The influence of bioactive charcoal compost addition on beight growth of bulian (E.zwageri) and gabaru (A.malaccensis) seedlings until 4 month

Perbedaan respon yang ditunjukkan oleh tanaman juga dapat disebabkan oleh adanya perbedaan kandungan hara dari masing-masing campuran media, sehingga akan berakibat pada perbedaan intensitas perbaikan kesuburan tanah. Seperti pada perlakuan B4-B6 dengan perlakuan B7-B9, pada gambar terlihat perbedaan yang cukup signifikan walaupun medianya sama-sama ditambah arkoba, tetapi B4-B6 hanya arkoba serbuk gergaji, sedangkan B7-B9 merupakan campuran arkoba serbuk gergaji dan jerami padi, sehingga menimbulkan perbedaan kandungan unsur hara yang berakibat juga pada perbedaan respon dari tanaman.

Hasil analisis statistik menunjukkan bahwa media memberikan perbedaan nyata terhadap pertambahan tinggi ke dua jenis anakan. Pada Gambar 2 juga terlihat bahwa pertambahan tinggi ke dua jenis anakan pada perlakuan B5 dan B6 mencapai 3 kali lipat dibanding kontrol dalam waktu 4 bulan. Hal yang sama juga dijumpai pada perlakuan B8 dan B9 pertambahan tinggi ke dua jenis anakan bahkan mencapai 4 kali lipat dibanding kontrol dalam waktu 4 bulan. Pada Tabel 3 dapat diketahui bahwa kombinasi perlakuan media, berpengaruh nyata terhadap pertambahan tinggi anakan bulian ( $E$ qwageri) dan gaharu (A. malaccensis).

Hasil uji lanjut menurut metode Scheffe (Lampiran), perbandingan antara B0 (kontrol) dengan gabungan perlakuan sangat berbeda nyata. Demikian juga perbandingan antara 
perlakuan K (kompos) dengan ASG dan ASGJ sangat berbeda nyata. Perbandingan diantara perlakuan K 15\% dengan K 30\% tidak berbeda nyata, tetapi berbeda sangat nyata dibanding dengan K 50\%. Begitu juga antara K 30\% dengan K 50\% sangat berbeda nyata terhadap tinggi anakan bulian. Untuk pertambahan tinggi anakan gaharu perlakuan $\mathrm{K} 15 \%$ tidak berbeda nyata dengan K $30 \%$, tetapi berbeda nyata dengan K 50\%. Perlakuan K $30 \%$ tidak berbeda nyata dengan $\mathrm{K} 15 \%$, tetapi berbeda nyata dengan $\mathrm{K} 50 \%$.

Perbandingan diantara perlakuan ASG menurut metode Scheffe terhadap tinggi anakan bulian menunjukkan bahwa perlakuan ASG $15 \%$ berbeda sangat nyata dengan perlakuan ASG 30\% dan ASG 50\%, tetapi antara ASG 30\% dengan ASG 50\% tidak berbeda nyata, sehingga saran untuk penerapan adalah ASG 30\%. Terhadap tinggi anakan gaharu ASG $15 \%$ tidak berbeda nyata dengan ASG $30 \%$, tetapi sangat berbeda nyata dengan ASG $50 \%$.

Perbandingan diantara perlakuan ASGJ menurut metode Scheffe terhadap tinggi anakan bulian menunjukkan bahwa perlakuan ASGJ 15\% berbeda nyata dengan perlakuan ASGJ $30 \%$ dan ASGJ 50\%, tetapi antara perlakuan ASGJ 30\% dan ASGJ 50\% tidak berbeda nyata. Terhadap tinggi anakan gaharu perlakuan ASGJ 15\% tidak berbeda nyata terhadap ASGJ $30 \%$, tetapi berbeda sangat nyata dengan ASGJ $50 \%$.

\section{Pertambahan Diameter Anakan}

Penambahan arkoba baik ASG maupun ASGJ pada media tanam anakan bulian dan gaharu ternyata dapat meningkatkan laju pertambahan diameter tanaman. Hasil penelitian pertambahan diameter anakan dapat dilihat pada Tabel 4.

Tabel 4. Rataan pertambahan diameterbatang anakan bulian dan gaharu selama4 bulan Table 4. Means of bulian (E.zwageri) and gabaru (A. malaccensis) diameter growth of seedlings during 4 month

\begin{tabular}{|c|c|c|}
\hline \multirow{2}{*}{$\begin{array}{l}\text { Perlakuan } \\
\text { (Treatment) }\end{array}$} & \multicolumn{2}{|c|}{$\begin{array}{l}\text { Pertambahan diameter } \\
\text { (Diameter growth), } \mathrm{cm}\end{array}$} \\
\hline & $\begin{array}{c}\text { Bulian } \\
\text { (E.zwager) }\end{array}$ & $\begin{array}{l}\text { Gaharu }(A . \\
\text { malaccensis })\end{array}$ \\
\hline B0 (Kontrol/Control) & $0,26 \mathrm{f}$ & $0,24 \mathrm{e}$ \\
\hline B1 Kompos (Compost) 15\% & 0,30 ef & 0,29 de \\
\hline B2 Kompos (Compost) 30\% & $0,32 \mathrm{e}$ & $0,30 \mathrm{~d}$ \\
\hline B3 Kompos (Compost) 50\% & $0,33 \mathrm{e}$ & $0,34 \mathrm{~d}$ \\
\hline B4 ASG (Sawdust bioactive charcoal compost) $15 \%$ & $0,58 \mathrm{~d}$ & $0,61 \mathrm{c}$ \\
\hline B5 ASG (Sawdust bioactive charcoal compost) $30 \%$ & $0,69 \mathrm{c}$ & $0,69 \mathrm{~b}$ \\
\hline B6 ASG (Sawdust bioactive charcoal compost) $50 \%$ & $0,70 \mathrm{c}$ & $0,71 \mathrm{~b}$ \\
\hline B7 ASGJ (Sawdust + rice straw bioactive charcoal compost) $15 \%$ & $0,91 \mathrm{~b}$ & $0,93 \mathrm{ab}$ \\
\hline B8 ASGJ (Sawdust + rice straw bioactive charcoal compost) $30 \%$ & $0,98 \mathrm{a}$ & $0,94 \mathrm{a}$ \\
\hline B9 ASGJ (Sawdust + rice straw bioactive charcoal compost) $50 \%$ & $1,01 \mathrm{a}$ & $1,05 \mathrm{a}$ \\
\hline
\end{tabular}

Keterangan (Remarks) : Angka yang diikuti huruf sama pada kolom yang sama tidak berbeda nyata pada uji Duncan taraf 5\% (Numbers followed by the same letters in the same column are not significantly different by Duncan Test) 
Pada Tabel 4 dapat diketahui bahwa perlakuan media yang diberi arkoba (ASG dan ASGJ) menunjukkan pertambahan diameter batang anakan yang lebih baik jika dibandingkan dengan media yang dicampur dengan kompos $(\mathrm{K})$ dan kontrol.

Sama halnya dengan pertambahan tinggi anakan, penambahan arkoba baik ASG maupun ASGJ pada media tanam anakan bulian dan gaharu juga dapat meningkatkan laju pertambahan diameter batang tanaman. Hal ini juga disebabkan bahwa media yang dicampur dengan arkoba diketahui mengandung unsur hara makro lebih tinggi, nisbah $\mathrm{C} / \mathrm{N}$ yang sesuai serta nilai KTK yang relatif tinggi, sehingga menyebabkan pertumbuhan tanaman menjadi lebih baik dibandingkan dengan perlakuan media lainnya. Perlakuan ASGJ relatif lebih baik dibanding dengan perlakuan ASG. Hal ini juga berdasarkan kandungan unsur hara yang terkandung, dimana kandungan hara ASGJ sedikit lebih baik dibanding ASG. Hal ini mungkin disebabkan karena dalam proses pembuatannya serbuk gergaji dicampur dengan jerami padi.

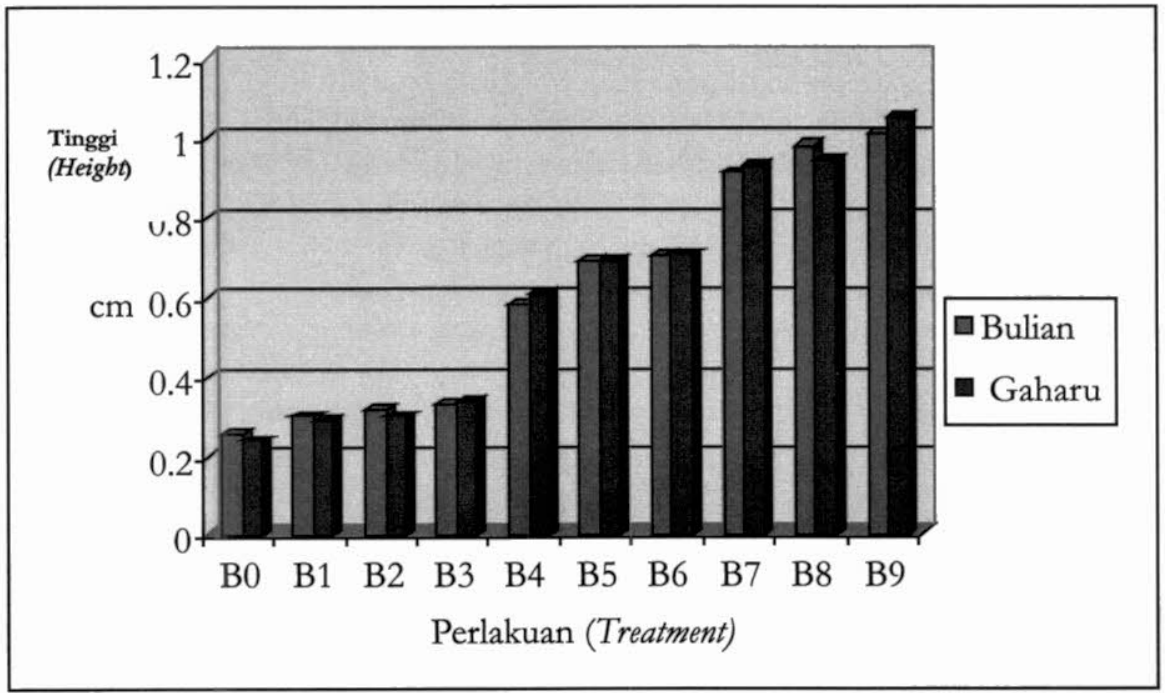

Gambar 4. Pengaruh pemberian arkoba terhadap pertambahan diameter batang anakan bulian (E.zwageri) dan gaharu (A.malaccensis) selama 4 bulan.

Figure 4. The influence of bioactive charcoal compost addition on diameter growth of bulian (E.zwageri) and gabaru (A.malaccensis) seedlings until 4 month

Pada Gambar 3 dapat dilihat dengan jelas bahwa pertambahan diameter batang ke dua jenis anakan yang tumbuh pada media arkoba (B4-B9), 2 - 4 kali lebih baik dibanding kontrol (Bo) dan kompos biasa (B1-B3). Pertambahan diameter anakan bulian dan gaharu pada perlakuan B7-B9 lebih tinggi dibanding perlakuan B4-B6. Sama halnya dengan pertambahan tinggi, untuk penerapan aplikasi selanjutnya, perlakuan B8 lebih optimal dibanding B9, karena nilai pertambahan hanya berbeda sedikit, sehingga lebih ekonomis dalam pemakaian arkobanya. Perbedaan respon yang ditunjukkan oleh tanaman juga disebabkan karena adanya perbedaan kandungan hara dari masing-masing campuran media, sehingga akan berakibat pada perbedaan perbaikan kesuburan tanah. Berdasarkan analisis kandungan unsur hara, 
perlakuan B7-B9 adalah media yang dicampur dengan ASGJ, dimana kandungan unsur haranya relatif lebih tinggi dibanding dengan perlakuan B4-B6 yang menggunakan ASG sebagai campuran media. Hal inilah yang menyebabkan pertambahan diameter batang anakan pada media ASGJ lebih baik dari diameter batang anakan pada media ASG dan kompos.

ASGJ adalah arkoba yang dicampur dengan jerami, mempunyai kandungan $\mathrm{N}$ total lebih tinggi dibanding ASG. Hal ini disebabkan karena jerami adalah sumber bahan organik yang mempunyai $\mathrm{N}$ tinggi. $\mathrm{N}$ merupakan unsur hara makro esensial, menyusun sekitar $1,5 \%$ bobot tanaman dan berfungsi terutama dalam pembentukan protein (Hanafiah, 2005). Menurut Hardjowigeno (2003), Nitrogen dalam tanah berasal dari: bahan organik tanah, bahan organik halus dan bahan organik kasar, pengikatan oleh mikroorganisme $\mathrm{N}$ dari udara, pupuk, dan air hujan. Sumber $N$ primer berasal dari atmosfer, dan lainnya berasal dari aktifitas di dalam tanah sebagai sumber sekunder. Fiksasi $\mathrm{N}$ secara simbiotik khususnya terdapat pada tanaman jenis leguminoseae dengan bakteri tertentu. $\mathrm{N}$ bahan organik juga bisa hilang/berkurang setelah mengalami proses dekomposisi oleh aktifitas jasad renik tanah. Fungsi $\mathrm{N}$ dalam proses fisiologis tumbuhan adalah untuk pembentukan klorofil, asam amino, lemak, enzim, dan persenyawaan lain. Jika pada media tumbuh tanaman tersedia $\mathrm{N}$ dalam jumlah cukup, maka pertumbuhan vegetatif tanaman akan lebih baik dan cepat.

Hasil analisis statistik menunjukkan bahwa faktor media (B) memberikan perbedaan nyata terhadap pertambahan diameter batang ke dua jenis anakan. Dari Tabel 5 dapat diketahui bahwa kombinasi perlakuan media, berpengaruh nyata terhadap pertambahan diameter batang anakan bulian ( $E$ zwageri) dan gaharu (A. malaccensis).

Diketahui bahwa keberadaan arang dalam arkoba memberikan pengaruh yang nyata terhadap pertambahan tinggi maupun batang anakan. Hal ini disebabkan karena arang mempunyai beberapa kelebihan antara lain: mempunyai pori-pori yang dapat menyerap dan menyimpan air serta unsur hara (Gusmailina et al., 2002). Keunggulan arkoba lainnya adalah karena keberadaan arang yang menyatu dalam kompos, yang bila diberikan pada tanah ikut andil dan berperan sebagai agent pembangun kesuburan tanah, sebab arang mampu meningkatkan $\mathrm{pH}$ tanah sekaligus memperbaiki sirkulasi air dan udara di dalam tanah (Gusmailina et al., 2002).

Penambahan arkoba pada media tumbuh, dapat meningkatkan porositas dan kesuburan, gembur dan subur, jumlah bulu akar sehingga pertumbuhan tanaman akan lebih baik dan sempurna. Hasil penelitian Komarayati et al., (2001), menunjukkan bahwa arang kompos bila dicampurkan pada tanah akan memperbaiki kondisi fisik, kimia dan biologi tanah serta sistim perakaran tanaman. Hal ini disebabkan karena arkoba dapat menambah ketersediaan unsur hara tanah, meningkatkan $\mathrm{pH}$ dan nilai KTK tanah. Arkoba mempunyai sifat yang lebih baik dari kompos biasa karena keberadaan arang yang menyatu dalam kompos. Morfologi arang yang mempunyai pori sangat efektif untuk mengikat dan menyimpan hara. Hara tersebut dilepaskan secara perlahan sesuai dengan konsumsi dan kebutuhan tanaman (efek slow release). Karena itu hara tersebut tidak mudah tercuci, sehingga lahan akan selalu berada dalam kondisi siap pakai. Pernyataan ini didukung beberapa hasil penelitian yang telah dilakukan oleh Gusmailina et al., 2000; Gusmailina et al., 2002; Gusmailina et al., 2000; Komarayati et al., 2003; Komarayati et al., 2004 dan Komarayati, 2004).

Hasil uji lanjut menurut metode Scheffe, perbandingan antara B0 (kontrol) dengan gabungan perlakuan sangat berbeda nyata terhadap pertambahan diameter batang ke dua jenis anakan. Demikian juga perbandingan antara perlakuan K (kompos) dengan ASG dan 
ASGJ sangat berbeda nyata. Perbandingan diantara perlakuan K 15\% dengan K 30\% juga menunjukkan pengaruh yang sangat nyata. Untuk pertambahan diameter anakan bulian perlakuan K $15 \%$ berbeda nyata dengan K $30 \%$, sangat berbeda nyata dengan K $50 \%$. Perlakuan K 30\% berbeda nyata dengan K 15\% dan K 50\%. Terhadap pertambahan diameter anakan gaharu $\mathrm{K} 15 \%$ tidak berbeda nyata dengan K 30\%, tapi sangat berbeda nyata dengan K $50 \%$. K $30 \%$ tidak berbeda nyata dengan K $15 \%$, tapi berbeda sangat nyata dengan K $50 \%$. K $50 \%$ berbeda sangat nyata dengan $\mathrm{K} 155 \%$ dan $\mathrm{K} 30 \%$.

Perlakuan ASG terhadap pertambahan diameter anakan bulian menunjukkan bahwa perlakuan ASG $15 \%$ berbeda sangat nyata dengan perlakuan ASG 30\% dan ASG 50\%. Antara ASG 30\% dan ASG 50\% berbeda nyata, sehingga saran untuk penerapan adalah ASG $30 \%$. Terhadap tinggi anakan gaharu ASG $15 \%$ berbeda sangat nyata dengan ASG $30 \%$ dan ASG 50\%. ASG 30\% berbeda nyata dengan ASG 15\%, tetapi tidak berbeda nyata dengan ASG 50\%. ASG 50\% tidak berbeda nyata dengan ASG 30\%, tapi sangat berbeda nyata dengan ASG $15 \%$.

Perbandingan diantara perlakuan ASGJ menurut metode Scheffe terhadap tinggi anakan bulian menunjukkan bahwa perlakuan ASGJ 15\% berbeda sangat nyata dengan perlakuan ASGJ 30\% dan ASGJ 50\%, tetapi perlakuan ASGJ 30\% dan ASGJ 50\% tidak berbeda nyata. Terhadap tinggi anakan gaharu perlakuan ASGJ 15\% tidak berbeda nyata terhadap ASGJ $30 \%$, tetapi berbeda sangat nyata dengan ASGJ 50\%. ASGJ 30\% tidak berbeda nyata dengan ASGJ $15 \%$, tetapi berbeda sangat nyata dengan ASGJ $50 \%$.

\section{KESIMPULAN}

1. Secara keseluruhan pertumbuhan anakan bulian dan gaharu pada media arkoba lebih baik dari media lain yang diterapkan dalam percobaan ini.

2. Persentase tumbuh anakan bulian (E. Zwageri) dan gaharu (A. malaccensis) pada media arkoba serbuk gergaji (ASG) dan arkoba serbuk gergaji + jerami padi (ASGJ) yaitu 100\%, lebih baik dibanding dengan persentase tumbuh anakan yang tumbuh pada media kompos, yaitu masing-masing gaharu $89 \%$ dan bulian $93 \%$, sedangkan persentase tumbuh anakan pada media kontrol hanya $81-87 \%$.

3. Pemberian arkoba ASG dan ASGJ berpengaruh nyata terhadap pertambahan tinggi dan diameter anakan bulian dan gaharu.

4. Perlakuan ASG dan ASGJ dapat meningkatkan pertambahan tinggi dan diameter anakan masing-masing 2 dan 4 kali lipat dibanding kontrol.

5. Perlakuan B9 (ASGJ 50\%) merupakan campuran ideal, namun untuk penerapan dalam praktek perlakuan B8 (ASGJ 30\%) lebih ekonomis dan efisien. 


\section{DAFTAR PUSTAKA}

Anonim, 2000. Pedoman pengharkatan hara kompos. Laboratorium Natural Products, SEAMEO - BIOTROP. Bogor.

Anonim, 2009. Siklus mineral. Bahan Kuliah Biotani. Fakultas MIPA, Universitas Lampung. Lampung

Gusmailina, G. Pari dan S. Komarayati. 2000. Teknik penggunaan arang sebagai “ Soil Conditioning” pada tanaman. Laporan Proyek Pusat Penelitian Hasil Hutan. Badan Litbang Kehutanan. Bogor (Tidak diterbitkan).

Gusmailina, G. Pari dan Sri Komarayati. 2002 (a). Pedoman Pembuatan Arang Kompos. Pusat Penelitian dan Pengembangan Teknologi Hasil Hutan. Badan Penelitian dan Pengembangan Kehutanan. Bogor. ISBN: 979-3132-27

Gusmailina, S. Komarayati ; G. Pari dan D. Hendra. 2002. Arang serbuk gergaji memperbaiki kesuburan tanah. Prosiding Seminar Nasional dan Pameran Pertanian Organik. Badan Litbang pertanian. Jakarta. 2-3 Juli. Hal 43.

Gusmailina, G. Pari dan S. Komarayati. 2002 (b). Kajian Teknis dan Implementasi Produksi POSG (Pupuk Organik Serbuk Gergaji). Laporan Kerjasama antara P3THH Bogor, JIFPRO Jepang, Dinas Kehutanan Propinsi Tk I Jambi dan Koperasi Sawmill Siginjai, Sengeti Muaro Jambi, Jambi. (Tidak diterbitkan)

Gusmailina, S. Komarayati, G. Pari dan M. Ali. 2005. Mengenal manfaat arang dan arang kompos. 17 Pebruari 2005. Diskusi Intern $\mathrm{BP}_{2} \mathrm{HT}-\mathrm{IBB}$, Palembang.

Gusmailina, Saepulloh, Mahpudin, dan S. Komarayati. 2006. Aplikasi dan diseminasi arang kompos bio aktif; Teknologi inovatif untuk mendukung gerhan dan pembangunan kehutanan yang berkesinambungan. Gelar Teknologi, Cianjur 13 Desember 2006. Kerjasama Pusat Penelitian dan Pengembangan Hasil Hutan dengan Dinas Kehutanan Kabupaten Cianjur.

Gusmailina, 2007. Mengeliminasi Kemungkinan Kegagalan GERHAN Melalui teknologi dan Aplikasi Arang Kompos Bioaktif. Buku panduan dalam rangka Pelatihan Peningkatan Pelatihan peningkatan Kualitas arang Kompos Bioaktif di Kabupaten Garut. 12 Desember 2007. Kerjasama Dinas Kehutanan Kabupaten Garut dengan KopKar GEPAK Wira Satria Sejati.

Gusmailina, 2007. Pembuatan arang dan arang kompos dari limbah PLTB. Makalah pada Acara Gelar Teknologi Penyiapan Lahan Tanpa Bakar (PLTB). Palembang 29 Nopember Kerjasama. Puslitbang Hutan Tanaman dan Balai Penelitian Kehutanan Palembang.

Gusmailina dan S. Komarayati. 2008. Teknologi inovasi penanganan limbah industri pulp dan kertas menjadi arang kompos bioaktif. Prosiding Seminar Teknologi Pemanfaatan Limbah Industri Pulp dan Kertas Untuk Mengurangi Beban Lingkungan. Bogor 24 November. Pusat Penelitian dan Pengembangan Hasil Hutan, Bogor. Hal:18-30 
Gusmailina, 2009. Arang kompos bioaktif; inovasi teknologi pemanfaatan limbah dalam rangka menunjang pembangunan kehutanan yang berkesinambungan.Makalah Gelar Teknologi Palembang, 4 Mei 2009. Kerjasama Puslitbang Hutan Tanaman dan Balai Penelitian Kehutanan Palembang. Muara Enim, Palembang.

Hakim N, M.Y. Nyakpa, A.M Lubis, S.G Nogroho, M.R. Saul, M.A. Diha, Go Bang Hong, H.H. Bailey, 1986, Dasar-DasarIlmu Tanah, Penerbit Universitas Lampung, Lampung

Hanafiah, K. A., A. Napoleon, N Ghofur. 2005. Biologi Tanah Ekologi \& Mikrobiologi Tanah. Penerbit Rajawali Pers. pp184. Jakarta

Hardjowigeno, 2003, Klasifikasi Tanah Dan Pedogenesis. Penerbit Akademika Presindo, Jakarta

Komarayati, S., Gusmailina dan G. Pari. 2001. Pemanfaatan limbah kulit kayu dan serasah tusam untuk kompos dan arang kompos. Laporan Hasil Penelitian. Proyek DIK-S. Sumber Dana Reboisasi. Tahun Anggaran 2001.

Komarayati, S., Gusmailina dan G. Pari. 2002. Pembuatan kompos dan arang kompos dari serasah dan kulit kayu tusam. Buletin Penelitian Hasil Hutan. 20 (3) : 231 - 242. Pusat Litbang Teknologi Hasil Hutan, Bogor.

Komarayati, S., Gusmailina dan G. Pari. 2003. Aplikasi arang kompos pada anakan tusam (Pinus merkusii). Buletin Penelitian Hasil Hutan. 21 (1) : 15 - 21. Pusat Litbang Teknologi Hasil Hutan. Bogor.

Komarayati, S. 2004. Penggunaan arang kompos pada media tumbuh anakan mahoni. Jurnal Penelitian Hasil Hutan. 22 (4) : 193 - 203. Pusat Litbang Teknologi Hasil Hutan. Bogor.

Komarayati, S., Gusmailina dan G. Pari. 2004. Application of compost charcoal on two species of forestry plants. Voluntary paper. Proceeding of The International Workshop on "Better Utilization of Forest Biomass for Local Community and Environment" Bogor. 16-17 Maret. Pusat Litbang Hasil Hutan dan JIFPRO.

Leiwakabessy, F.M. 1988. Kesuburan Tanah. Jurusan Tanah Fakultas Pertanian. Institut Pertanian Bogor. Bogor.

Saeni, S.M dan Latifah, D. 1990. Panduan Praktikum Kimia Lingkungan. Jurusan Kimia FMIPA-IPB. Bogor

Steel, R.G.D. dan Torrie, J.H. 1991. Prinsip dan Prosedur Statistika (Terjemahan) PT. Gramedia Pustaka Utama. Jakarta. 


\section{Lampiran}

Hasil uji lanjut perbandingan B0 (kontrol) dengan semua perlakuan (ASG dan ASGJ) serta analisis perbandingan diantara masing-masing perlakuan dengan menggunakan cara Scheffe. (Result of Scheffe method of camparison BO (control) with all treatment (ASG and ASGJ) and comparison among treatments)

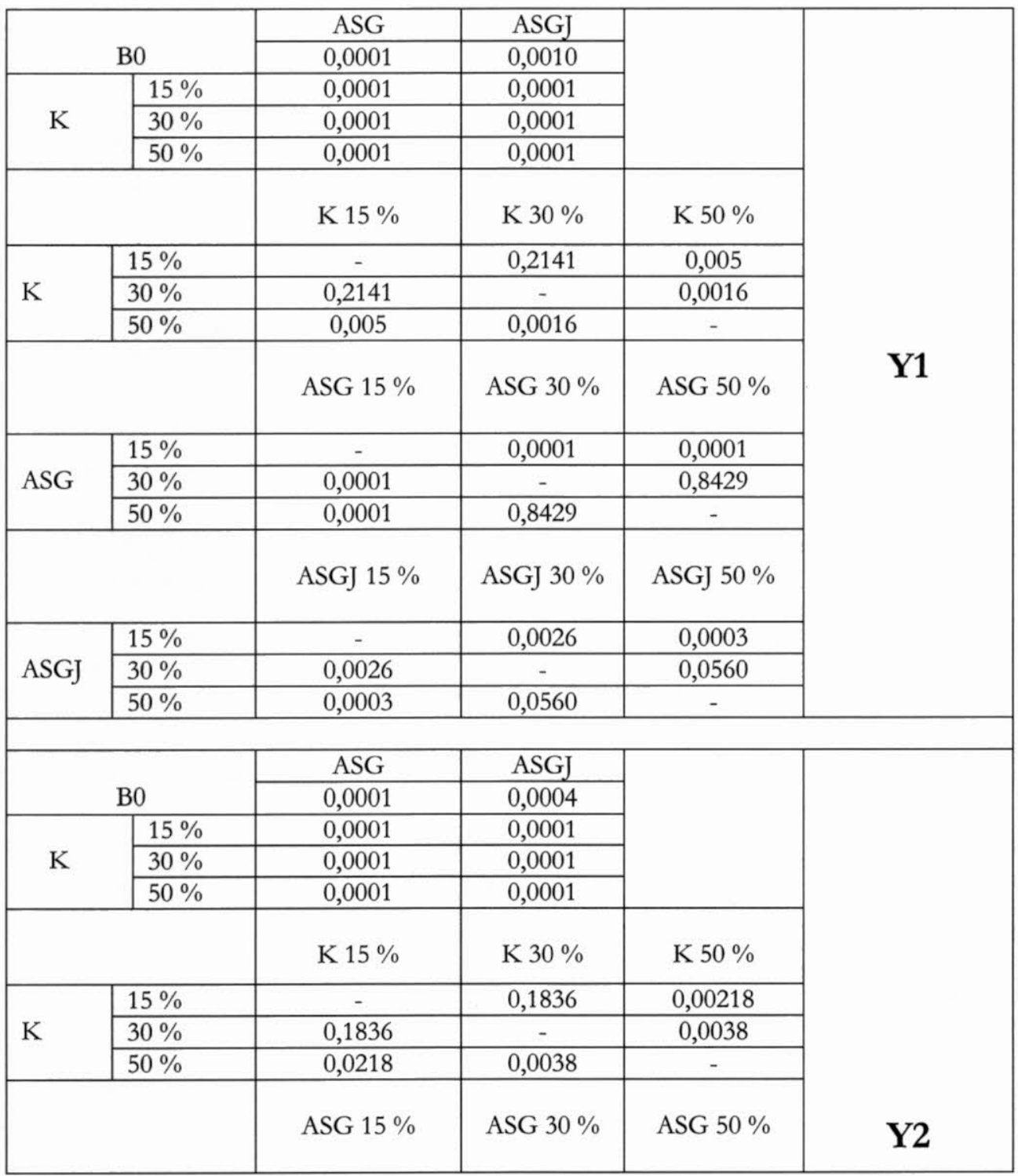




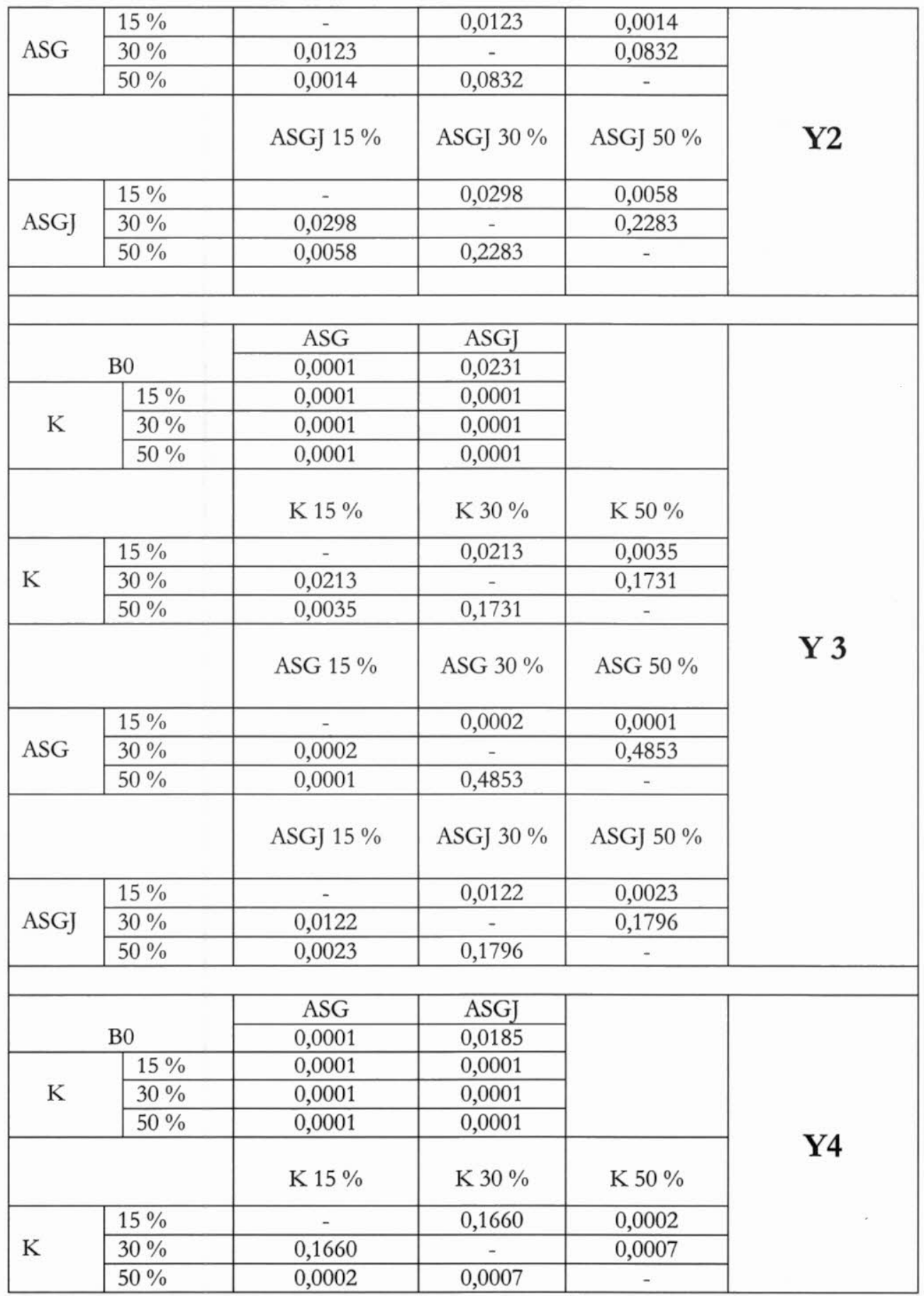




\begin{tabular}{|c|c|c|c|c|c|}
\hline & & ASG $15 \%$ & ASG $30 \%$ & ASG $50 \%$ & \multirow{8}{*}{ Y4 } \\
\hline \multirow{3}{*}{ ASG } & $15 \%$ & - & 0,0011 & 0,0003 & \\
\hline & $30 \%$ & 0,0011 & - & 0,1948 & \\
\hline & $50 \%$ & 0,0003 & 0,1948 & - & \\
\hline & & ASGJ $15 \%$ & ASGJ $30 \%$ & ASGJ $50 \%$ & \\
\hline \multirow{3}{*}{ ASGJ } & $15 \%$ & - & 0,6332 & 0,0009 & \\
\hline & $30 \%$ & 0,6332 & - & 0,0015 & \\
\hline & $50 \%$ & 0,0009 & 0,0015 & - & \\
\hline
\end{tabular}

Keterangan (Remarks) : Y1 = pertambahan tinggi anakan bulian, $\mathrm{cm}$ (bulian growth height, $\mathrm{cm})$; $\mathrm{Y} 2=$ pertambahan tinggi anakan gaharu, $\mathrm{cm}$ (gaharu growth beight, $\mathrm{cm}) ; \mathrm{Y} 3=$ pertambahan diameter batang anakan bulian, $\mathrm{cm}$ (bulian growth diameter, $\mathrm{cm}$ ); $\mathrm{Y} 4=$ pertambahan diameter batang anakan gaharu, $\mathrm{cm}$ (gaharu growth diameter, $\mathrm{cm}$ ); $\mathrm{B} 0=$ kontrol (tanpa perlakuan) (control/ without tratment) ASG $=$ Arkoba serbuk gergaji (sawdust bioactive charcoal compost); ASGJ = Arroba serbuk gergaji + jerami padi (sawdust + rice straw bioactive charcoal compost) 